Check for updates

\section{London}

Cite this as: $B M / 2021 ; 372: \mathrm{n} 100$ http://dx.doi.org/10.1136/bmj.n100 Published: 12 January 2021

\title{
Covid-19: Deaths rise after Christmas in England and Wales
}

\section{Shaun Griffin}

Nearly a third (31.2\%) of all deaths in England and Wales in the week ending 1 January involved covid-19, show data from the Office for National Statistics.

Some 11541 deaths were registered in that week, 2304 more than the five year average and 220 more than the previous week. Of these, 3417 deaths involved covid-19.

Although comparison with previous years is complicated by the number of bank holidays among other issues, experts expressed concern that the total number of deaths was already slightly higher than those in the previous week. "That increase will become much bigger as more deaths are registered," said Kevin McConway, professor of applied statistics at the Open University.

\section{Regional variations}

Despite the complication from registration delays, the number of deaths from all causes was higher in London and Wales in the week ending 1 January, "illustrating the seriousness of the pandemic there," McConway added.

In London and Wales some $43 \%$ of deaths involved covid-19, while in the East and South East England regions the figure was nearly a third. Elsewhere, more than a quarter of deaths involved covid, with the exception of South West England, where the proportion was $17 \%$.

At 75925 higher than the five year average, the number of deaths registered in 2020 was "unprecedented," said Sarah Caul, head of mortality analysis at the Office for National Statistics, in a blog accompanying the data. ${ }^{2}$ It also represented "the biggest year-on-year increase since 1940,” although population expansion, changes in demographics, and medical advances complicate comparisons, she noted.

With age standardised calculations, the mortality rate in 2020 was 1043.5 deaths per 100000 population-around $8 \%$ higher than the five year average and the highest since 2008.

\section{Care homes and private homes}

The Office for National Statistics' year-to-date analysis showed that, of deaths involving covid-19 up to the week ending 1 January, $67.8 \%$ of deaths (55 372) occurred in hospital, 20661 in care homes, 3942 in private homes, and 1694 elsewhere.

Sarah Scobie, the Nuffield Trust's deputy director of research, said, "By the end of last year, we had already seen an increase in the number of covid registered deaths. With the dramatic and rapid rise in cases following the looser restrictions over the festive period and the severe impact this is having on health services, we can only expect these numbers to grow further for some time.
"The majority of these deaths are taking place in hospitals, but it is very concerning to see within this latest set of data that the number of covid deaths in care homes is rising. This rise, coupled with an increase in the number of outbreaks of covid in care homes, paints a worrying picture.”

Experts have also continued to express concerns about the lack of clarity on the reasons for the worrying numbers of deaths in private homes, which are around 100 above the expected number each day, as they have been since the first wave of the pandemic.

\section{Office for National Statistics. Deaths registered weekly in England and Wales, provisional: week ending 1 January 2021. 12 Jan 2021. https://www.ons.gov.uk/peoplepopulationandcommunity/birthsdeathsand- marriages/deaths/bulletins/deathsregisteredweeklyinenglandandwalespro- visional/weekending1january2021. \\ 2 Caul S. Counting deaths involving coronavirus: a year in review. 12 Jan 2021 https://blog.ons.gov.uk/2021/01/12/counting-deaths-involving-coronavirus- a-year-in-review/.}

This article is made freely available for use in accordance with BMJ's website terms and conditions for the duration of the covid-19 pandemic or until otherwise determined by BMJ. You may use, download and print the article for any lawful, non-commercial purpose (including text and data mining) provided that all copyright notices and trade marks are retained. 